\title{
Let's Talk and Grow Together: A Bidirectional Communication between Granulosa- and Oocyte- Derived Factors in the Ovary
}

\author{
Subhasri Biswas and Sudipta Maitra* \\ Department of Zoology, Visva-Bharati University, India
}

Submission: May 23, 2017; Published: July 05, 2017

*Corresponding author: Sudipta Maitra, Department of Zoology, Visva-Bharati University, India, Tel: +91-8116978904,

Email:smaitra3@gmail.com

\begin{abstract}
Reproduction, one of the most active and appealing area of research for endocrinologists and reproductive biologists since many a years, has several faces that remains to be unmasked in terms of its regulatory aspects. Available information on the regulation of oocyte development and maturational competence are gaping and needs elucidation to achieve utmost quality of eggs, a major area of concern. The notion of the somatic follicular cells providing an appropriate microenvironment for the development of oocyte throughout its journey has been replaced with the current perception of a complex yet regulated cross-talk between the granulosa-and oocyte-derived factors to orchestrate follicle development. Interestingly, actions of FSH and LH are mediated or modulated by these locally produced non-steroidal peptide factors from the follicular layer and the oocyte itself (insulin-like growth factors (IGFs), epidermal growth factor (EGF) family members, TGF $\beta$ super family members etc.), forming an intimate regulatory network within the ovarian follicles. Present article will provide a deeper insight into the need and underlying mechanisms of action of these growth factors in the intraovarian network to sustain a healthy oocyte.
\end{abstract}

Keywords: Oocyte; Follicular layer; Theca; Granulosa; Growth factors; IGF; IGFR; EGF; EGFR; Maturational competence

\section{Introduction}

In the present scenario of environment and its associated external factors, reproduction seems to pave new ways out for maintaining intimate, well-organized axes to help an organism develop its gamete of utmost quality and undergo positive successful fertilization. Achieving high quality eggs is a major arena of discussion and research for the fact that there still remains major gap in the molecular and physiological mechanisms underlying the production of such eggs. Considering the importance of intelligently designed oocyte for a female and the negative consequences that may occur due to impairment of the complex dialogue between neuro-endocrine, endocrine and locally produced autocrine/paracrine factors within the ovarian follicles, the indispensable signaling pathways involved in producing such a maturationally competent oocyte need to be unravelled. An oocyte is the mother of existence and is nursed upon by its surrounding follicular layer till the point it reaches the ability to mature. However, the concept of the oocyte as a passive partner, subjected to control by the follicle cells, is no longer plausible and recent evidences have pointed towards the participation of granulosa- and oocyte-derived non-steroidal peptide factors in modulating functions of each other indicating the existence of a bidirectional communication between both the compartments. Though it is well-known that follicular growth and oocyte maturation are dependent primarily on pituitaryderived gonadotropins, follicle stimulating hormone (FSH) and luteinizing hormone ( $\mathrm{LH})$, pictures emerging from recent studies have put forward the potential involvement of these local factors, more specifically growth factors, to integrate with endocrine inputs and control ovarian and follicle development [1,2]. These factors include (but not limited to) mainly insulin-like growth factors (IGFs) [3-5], epidermal growth factor (EGF) [6,7], and transforming growth factor $\beta$ (TGF $\beta$ ) super family $[8,9]$. The IGF system comprises of ligands (IGFI and IGFII), receptors (IGFIR and IGFIIR), IGF binding proteins (IGFBP 1 to -7) and IGFBP proteases [10]. In mammals as in other vertebrate models studied so far, binding of IGF ligands (members of insulin super family), to their cognate receptors, IGFIR (a trans- membrane receptor that belongs to the tyrosine kinase family of receptors) and IGFIIR (a trans- membrane mannose 6-phosphate receptor), plays essential role in the regulation of cell growth, proliferation and survival [10-12]. 


\section{Global Journal of Reproductive Medicine}

Though IGFs have shown to have cardinal influence in most other organ systems, information on ovary as a major site of IGF synthesis, reception and action is from recent past [13]. All components of the somatotrophic axis, including GH, IGFs and their receptors are expressed in the ovary of both mammals and fish $[4,14,15]$ suggesting the existence of an intra-ovarian GH-IGF mini-axis in vertebrates [16]. PI3K activation has been implicated in growth factor-induced resumption of meiosis in mammalian, amphibian and teleost oocytes [17-19]. The action of PI3K on oocyte is mediated via downstream Akt/PKB that in turn regulates multiple cellular changes including cell polarization, re-entry into cell cycle, cell survival and oocyte maturation [20]. Active Akt/PKB is sufficient to promote oocyte maturation through oocyte-specific PDE3, the enzyme that degrades and inactivates cAMP [18,19]. Several earlier studies have also reported activation of MAPKs during IGF stimulation of meiotic maturation that involves the participation of GTPbinding protein, p21 Ras and serine/threonine kinase Raf [21]. Since its detection in vertebrate ovary, several studies have been conducted to identify the physiological significance of IGF system in regulating ovarian function under normal as well as pathological condition [22]. In mammals, IGFs role in reproduction includes modulation of steroidogenesis, oocyte maturation, follicular growth and survival of growing oocytes [14]. IGFI enhances FSH-stimulated progesterone accumulation rat granulosa cells [23]. While granulosa cells appear to be the site of IGFI gene expression [24], in rat ovary, expression of type-I IGF receptor has been reported in both granulosa [25] and theca- interstitial cells [26]. In mouse targeted null-mutation of the IGFI gene results in infertility, secondary to failure to ovulate even after administration of gonadotropins [27]. Interestingly, earlier decades have even evidences of existence of well-coordinated IGF system in human, rodent and primate uterus, with its expression being regulated by sex steroids suggesting its role in modulating the proliferative effects of sex steroids [28-30]. So far as studies in sub-mammalian vertebrates specifically in fishes are concerned, IGFI and/or IGFII have been shown to act as potent regulators of oocyte maturation in red seabream [31], mummichog [32] and shortfined eel [33]. In zebrafish, IGFI acts synergistically with maturation-inducing steroid $(17,20 \beta-P)$ to overcome the estradiol inhibition of oocyte maturation [34]. Further, IGFIII, a gonad-specific follicular IGF ligand reported in zebrafish, has been documented to mediate gonadotropin-induced meiosis resumption [6]. Epidermal growth factor (EGF) family is yet another candidate recognized as the essential mediator of $\mathrm{LH}$ action on oocyte maturation in mammals $[7,35]$. Pre-ovulatory surge in LH promotes expression of EGF-like ligands including amphiregulin (AREG), epiregulin (EREG) and betacellulin (BTC) in mural granulosa cells and that of EGF receptor (EGFR) is concomitantly enhanced by oocyte-derived paracrine factors such as bone morphogenetic protein 15 (BMP15) and growth differentiation factor 9 (GDF9) [8]. As a result, MAPK (ERK1/2) activity is dramatically increased, thereby phosphorylating the gap junctions [36] and initiating the meiotic resumption in the oocyte [7,8,37] (Figure 1).

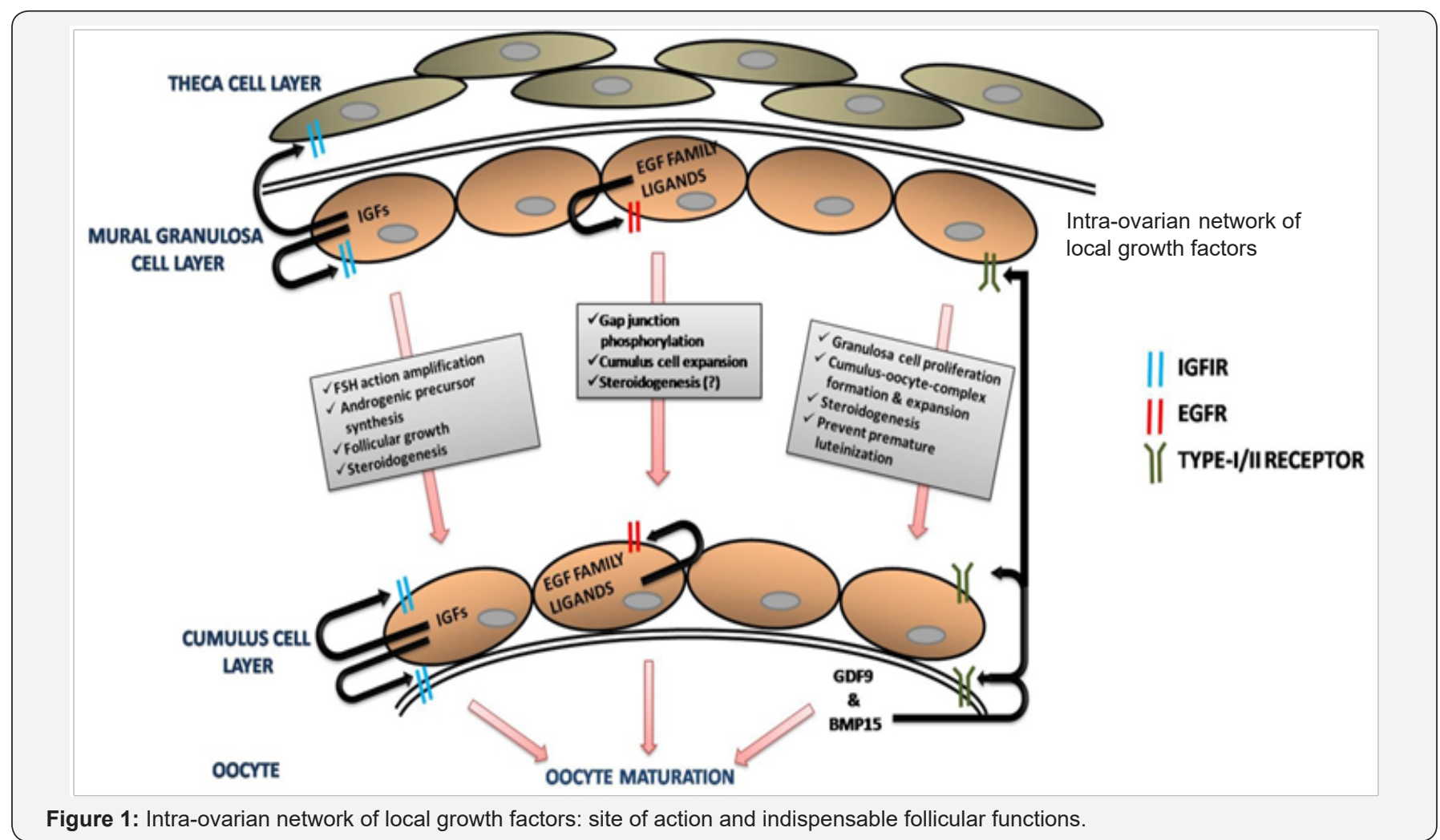




\section{Global Journal of Reproductive Medicine}

Further, FSH regulation of Egfr expression in granulosa cells corroborates well with cumulus expansion and oocyte maturation in mouse ovary [38]. However, unlike the situation in mammals, zebrafish ovary depicts a beautiful case of bidirectional communication wherein the members of EGF family, with BTC as exception, are secreted exclusively from the oocyte. These ligands, primarily EGF and TGF $\alpha$, upon receptor (EGFR) binding on follicular cells promotes activation of MAPK and synthesis of activins, which in turn act on the oocyte, activates Smad proteins and promote oocyte maturation [39,40]. Apart from its role in oocyte maturation through closure of gap junctions between cumulus cells and oocyte, EGFR has also been reported to trigger steroidogenesis in mammals, but the underlying mechanisms are not well-defined [35]. As mentioned earlier, oocytes do not merely reside inside the follicles and passively receive signals from follicular compartment, but it do dictate follicular cell differentiation and function for their own want via the local secretion of potent growth factors, termed as oocytesecreted factors [41]. Oocyte- derived factors, primarily GDF9 and BMP15, belong to the TGF- $\beta$ super family. GDF- 9 and BMP-15 are specifically expressed by oocytes of all mammalian species from the first stages of follicle development to ovulation $[42,43]$, suggesting their potential involvement in follicle development. These members of TGF- $\beta$ superfamily regulate gene expression by binding to and phosphorylating type-I and type-II receptors that in turn activates Smad1/5/8, forms a complex with Smad4 and translocates to nucleus to exert its function [44]. Studies in the human follicle cells have suggested that GDF9 and BMPs interact with pituitary gonadotropins to inhibit StAR expression and progesterone synthesis thereby preventing premature luteinization $[45,46]$. The absence of GDF-9 at the one-layer thick primary follicle results in blockage in folliculogenesis, potentially through failure in thecal cell expansion, leading to compromised oocyte quality [47]. Though BMP-15 null mice do not show gross defects in ovarian morphology and may not be obligatory during pre-antral folliculogenesis, in absence of BMP15 the animals are subfertile, considered secondary to decreased ovulation and fertilization rates [48]. Interestingly, expression levels of BMP-15 and GDF-9 tends to be higher in women with polycystic ovary syndrome [49], implicating the role of these oocyte-secreted factors in female reproductive pathology. On the contrary, studies in zebrafish revealed that BMP-15 has negative influence on oocyte maturation [50].

\section{Discussion}

Though at the cellular level these local autocrine/paracrine regulators, possibly act under the influence of pituitary Gth, their mechanism of action in the intraovarian network, their changing roles during ovarian development and interplay among themselves as well as their interactions with the endocrine hormones and/or the steroidal factors needs further elucidation. Any deregulation in these growth factor-mediated intra-follicular and/or intra-oocyte signaling cascades may lead to perturbation of ovarian functions and high risk of infertility and reproductive pathologies. Working with well characterized emerging models, e.g. zebrafish, would surely unveil the underlying molecular mechanisms required for development of maturationally competent eggs and may help establish a new path for improving fertility and treatment of ovarian disorders in vertebrates.

\section{Conclusion}

Thus an intimate intraovarian meshwork of factors derived from both follicular layer and oocyte forms the basis of a cross-talk between these compartments to sustain a balanced microenvironment, which in its turn helps in establishing the essence of bidirectional oocyte-follicular cell dialog.

\section{Acknowledgement}

SB was supported by University Grants Commission, New Delhi through award of Junior Research Fellowship. The authors are thankful to The Head, Department of Zoology, Visva-Bharati University for providing infrastructural facilities.

\section{References}

1. Buchanan R, Bonthius DJ (2012) Measles virus and associated central Albertini DF, Combelles CM, Benecchi E, Carabatsos MJ (2001) Cellular basis for paracrine regulation of ovarian follicle development. Reproduction 121(5): 647-653.

1. Gilchrist RB, Ritter LJ, Armstrong DT (2004) Oocyte-somatic cell interactions during follicle development in mammals. Anim Reprod Sci 82-83: 431-446

2. Xia P, Tekpetey FR, Armstrong DT (1994) Effect of IGF-I on pig oocyte maturation, fertilization, and early embryonic development in vitro, and on granulosa and cumulus cell biosynthetic activity. Mol Reprod Dev 38(4): 373-379.

3. Reinecke M (2010) Insulin-like growth factors and fish reproduction. Biol Reprod 82(4): 656-661.

4. Li J, Chu L, Sun X, Liu Y, Cheng CH (2015) IGFs mediate the action of LH on oocyte maturation in zebrafish. Mol Endocrinol 29(3): 373-383.

5. Park JY, Su YQ, Ariga M, Law E, Jin SL, et al. (2004) EGF-like growth factors as mediators of LH action in the ovulatory follicle. Science 303(5658): 682-684.

6. Su YQ, Sugiura K, Li Q, Wigglesworth K, Matzuk MM, et al. (2010) Mouse oocytes enable LH- induced maturation of the cumulus-oocyte complex via promoting EGF receptor-dependent signaling. Mol Endocrinol 24(6): 1230-1239.

7. Peng C (2003) The TGF- $\beta$ superfamily and its roles in the human ovary and placenta. J Obstet Gynaecol Can 25(10): 834-844.

8. Knight PG, Glister C (2006) TGF- $\beta$ superfamily members and ovarian follicle development. Reproduction 132(2): 191-206.

9. Lackey BR, Gray SL, Henricks DM (1999) The insulin-like growth factor (IGF) system and gonadotropin regulation: actions and interactions. Cytokine Growth Factor Rev 10(3-4): 201-217.

10. Wood AW, Duan C, Bern HA (2005) Insulin-like growth factor signalling in fish. Int Rev Cytol 243: 215-285.

11. Annunziata M, Granata R, Ghigo E (2011) The IGF system. Acta Diabetol 48(1): 19.

12. Behl R, Kaul R (2002) Insulin like growth factor 1 and regulation of ovarian function in mammals. Indian J Exp Biol 40: 25-30. 


\section{Global Journal of Reproductive Medicine}

13. Zhao J, Taverne MA, Van der Weijden GC, Bevers MM, van Den Hurk R (2002) Immunohistochemical localisation of growth hormone (GH), GH receptor (GHR), insulin-like growth factor I (IGF-I) and type I IGF-I receptor, and gene expression of GH and GHR in rat pre-antral follicles. Zygote 10(01): 85-94.

14. Kajimura S, Kawaguchi N, Kaneko T, Kawazoe I, Hirano T, et al. (2004) Identification of the growth hormone receptor in an advanced teleost, the tilapia (Oreochromis mossambicus) with special reference to its distinct expression pattern in the ovary. J Endocrinol 181(1): 65-76.

15. Zhou R, Yu SM, Ge W (2016) Expression and functional characterization of intrafollicular GH-IGF system in the zebrafish ovary. Gen Comp Endocrinol 232: 32-42.

16. Das D, Khan PP, Maitra S (2013) Participation of PI3-kinase/Akt signalling in insulin stimulation of p34cdc2 activation in zebrafish oocyte: phosphodiesterase 3 as a potential downstream target. Mol Cell Endocrinol 374: 46-55

17. Andersen CB, Roth RA, Conti M (1998) Protein Kinase B/Akt Induces Resumption of Meiosis in Xenopus Oocytes. J Biol Chem 273(30): 18705-18708.

18. Han SJ, Vaccari S, Nedachi T, Andersen CB, Kovacina KS, et al. (2006) Protein kinase B/Akt phosphorylation of PDE3A and its role in mammalian oocyte maturation. EMBO J 25(24): 5716- 5725.

19. Cantley LC (2002) The phosphoinositide 3-kinase pathway. Science 296(5573): 1655-1657.

20. Fabian JR, Morrison DK, Daar IO (1993) Requirement for Raf and MAP kinase function during the meiotic maturation of Xenopus oocytes. J Cell Biol 122: 645-652.

21. Guidice LC (1992) Insulin-like growth factors and ovarian follicular development. Endocr Rev 13(4): 641-669.

22. de Moura MD, Choi D, Adashi EY, Payne DW (1997) Insulin-like growth factor-I-mediated amplification of follicle-stimulating hormone-supported progesterone accumulation by cultured rat granulosa cells enhancement of steroidogenic enzyme activity and expression. Biol Reprod 56(4): 946-953.

23. Hernandez ER, Roberts CT, LeRoith D, Adashi EY (1989) Rat ovarian insulin-like growth factor-I (IGF-I) gene expression is granulosa cell-selective: 5'-untranslated mRNA variant representation and hormonal regulation. Endocrinology 125(1): 572-574.

24. Adashi EY, Resnick CE, Rosenfeld RG (1990) Insulin-like growth factor-I (IGF-I) and IGF-II hormonal action in cultured rat granulosa cells: Mediation via type I but not type II IGF receptors. Endocrinology 126(1): 216-222.

25. Cara JF, Fan J, Azzarello J, Rosenfeld RG (1990) Insulin-like growth factor-I enhances luteinizing hormone binding to rat ovarian theca-interstitial cells. J Clin Invest 86(2): 560-565.

26. Baker J, Hardy MP, Zhou J, Bondy C, Lupu F, et al. (1996) Effects of an Igf1 gene null mutation on mouse reproduction. Mol Endocrinol 10(7): 903-918.

27. Boehm KD, Daimon M, Gorodeski IG, Sheean LA, Utian WH (1990) Expression of the insulin-like and platelet-derived growth factor genes in human uterine tissues. Mol Reprod Dev 27(2): 93-101.

28. Sahlin L, Norstedt G, Eriksson H (1994) Estrogen regulation of the estrogen receptor and insulinlike growth factor-I in the rat uterus: a potential coupling between effects of estrogen and IGF-I. Steroids 59(7) 421-430.

29. Adesanya 00, Zhou J, Bondy CA(1996) Sex steroid regulation of insulin-like growth factor system gene expression and proliferation in primate myometrium. J Clin Endocrinol Metab 81(5): 1967-1974.
30. Kagawa H, Kobayashi M, Hasegawa Y, Aida K (1994) Insulin and insulin-like growth factors I and II induce final maturation of oocytes of red seabream, Pagrus major, in vitro. Gen Comp Endocrinol 95(2): 293300 .

31. Negatu Z, Hsiao SM, Wallace RA (1998) Effects of insulin-like growth factor-I on final oocyte maturation and steroid production in Fundulus heteroclitus. Fish Physiol Biochem 19(1): 13-21.

32. Lokman PM, George KA, Divers SL, Algie M, Young G (2007) 11-Ketotestosterone and IGF-I increase the size of previtellogenic oocytes from shortfinned eel, Anguilla australis, in vitro. Reproduction 133(5): 955967.

33. Das D, Pal S, Maitra S (2016) Releasing prophase arrest in zebrafish oocyte: synergism between maturational steroid and igf1. Reproduction 151(1): 59-72.

34. Jamnongjit M, Gill A, Hammes SR (2005) Epidermal growth factor receptor signaling is required for normal ovarian steroidogenesis and oocyte maturation. Proc Natl Acad Sci 102(45): 16257-16262.

35. Sela-Abramovich S, Chorev E, Galiani D, Dekel N (2005) Mitogen-activated protein kinase mediates luteinizing hormone-induced breakdown of communication and oocyte maturation in rat ovarian follicles. Endocrinology 146(3): 1236-1244.

36. Hsieh M, Lee D, Panigone S, Horner K, Chen R, et al. (2007) Luteinizing hormone-dependent activation of the epidermal growth factor network is essential for ovulation. Mol Cell Biol 27(5): 1914-1924.

37. El-Hayek S, Demeestere I, and Clarke HJ (2014) Follicle- stimulating hormone regulates expression and activity of epidermal growth factor receptor in the murine ovarian follicle. Proc Natl Acad Sci 111(47): $16778-16783$

38. Pang Y, Ge W (2002) Epidermal growth factor and TGF $\alpha$ promote zebrafish oocyte maturation in vitro: potential role of the ovarian activin regulatory system. Endocrinology 143(1): 47-54.

39. Chung CK, Ge W (2012) Epidermal growth factor differentially regulates activin subunits in the zebrafish ovarian follicle cells via diverse signaling pathways. Mol Cell Endocrinol 361(1): 133-142.

40. Russell DL, Gilchrist RB, Brown HM, Thompson JG (2016) Bidirectional communication between cumulus cells and the oocyte: Old hands and new players? Theriogenology 86(1): 62-68.

41. McGrath SA, Esquela AF, Lee SJ (1995) Oocyte-specific expression of growth/differentiation factor-9. Mol Endocrinol 9(1): 131-136.

42. Laitinen M, Vuojolainen K, Jaatinen R, Ketola I, Aaltonen J, et al. (1998) A novel growth differentiation factor-9 (GDF-9) related factor is co-expressed with GDF-9 in mouse oocytes during folliculogenesis. Mech Dev 78(1): 135-140

43. Drummond AE (2005) TGF $\beta$ signalling in the development of ovarian function. Cell Tissue Res 322(1): 107-115.

44. Shi FT, Cheung AP, Klausen C, Huang HF, Leung PC (2010) Growth differentiation factor 9 reverses activin A suppression of steroidogenic acute regulatory protein expression and progesterone production in human granulosa-lutein cells. J Clin Endocrinol Metab 95(10): E172E180.

45. Miyoshi T, Otsuka F, Suzuki J, Takeda M, Inagaki K, et al. (2006) Mutual regulation of follicle- stimulating hormone signaling and bone morphogenetic protein system in human granulosa cells. Biol Reprod 74(6): 1073-1082.

46. Carabatsos MJ, Elvin J, Matzuk MM, Albertini DF (1998) Characterization of oocyte and follicle development in growth differentiation factor-9-deficient mice. Dev Biol 204(2): 373-384.

47. Yan C, Wang P, DeMayo FJ, Elvin JA, Carino C, et al. (2001) Synergistic 
roles of bone morphogenetic protein 15 and growth differentiation factor 9 in ovarian function. Mol Endocrinol 15(6): 854-866.

48. Zhao SY, Qiao J, Chen YJ, Liu P, Li J, et al. (2010) Expression of growth differentiation factor- 9 and bone morphogenetic protein-15 in oocytes and cumulus granulosa cells of patients with polycystic ovary syndrome. Fertil Steril 94(1): 261-267
49. Tan Q, Balofsky A, Weisz K, Peng C (2009) Role of activin, transforming growth factor- $\beta$ and bone morphogenetic protein 15 in regulating zebrafish oocyte maturation. Comp Biochem Physiol A Mol Integr Physiol 153(1): 18-23. 